\title{
Impact of air born technogenic pollution on agricultural soils depending on prevailing winds in Polissya region (NW Ukraine)
}

\author{
Roman H. Fedoniuk*., Tatiana P. Fedoniuk, Anastasia A. Zimaroieva, Viktor M. Pazych, Olena V. Zubova
}

\author{
Zhytomyr National Agroecological University \\ Blvd. Staryy, 7, Zhytomyr, Ukraine \\ *e-mail: tanyavasiluk2015@gmail.com
}

Received: 21 May 2019 / Accepted: 10 December 2019

\begin{abstract}
The article presents the results of the research on air born technogenic pollution of agrolandscapes as a result of the receipt of non-localized inorganic dust from several industrial enterprises, which are concentrated in a small area (for example, the eastern industrial facilities in Zhytomyr). It has been stated that the activity of these enterprises involves the formation of dust containing high concentrations of $\mathrm{Mn}, \mathrm{Zn}, \mathrm{Pb}$ and $\mathrm{Cu}$. Thus, the article shows the concentration levels of dust in the air at different distances from the source of emission.

The role of wind characteristics in dissipation of pollutants within the limits of the given territory is determined. It is proved that dust pollution of the territory causes changes in soil texture. The increase in the fraction of the coarse dust is observed at the distance of up to $250 \mathrm{~m}$, of the medium dust - up to $400 \mathrm{~m}$, of the fine dust - up to $600 \mathrm{~m}$, the content of the smallest fractions increases from 50 and is kept to a height of up to $750 \mathrm{~m}$. Such soil composition near the eastern industrial site possesses a high soil permeability, poor water retention and absorption properties, low water resistance and buffering of pollutants, etc. Therefore, as a result of the redistribution of soil fractions, changes in the humidity regime and humus accumulation occur. It was revealed that the greatest danger in the immediate proximity to the industrial facilities is the formation of copper compounds that comes in coarse dust particles, its highest concentrations are noted in the 1-km zone, where the significant variability of pollution is noted - from 1 to 5 maximum permissible concentration, which determines by the role of wind streams in creating a general picture of pollution. All other investigated groups of pollutants - zinc, lead and manganese compounds - create a hazard in more distant areas, due to their receipt as a fine particle fraction of dust. The loss of these compounds is also marked by variability and heterogeneity within the studied area, which we also associate with variables of wind characteristics. It is these groups of compounds that create the greatest danger for the well-being of agroecosystems surrounding the area of the industrial facilities.
\end{abstract}

Key words: Airborn technogenic contamination, dust, heavy metals, toxicity, arable soils, Zhytomyr.

\section{Introduction}

For decades the pollution of atmospheric air remains an urgent and top-priority geoecological problem, highlighted in a considerable number of scientific publications. Many papers state that the mining and processing industries are the main sources of heavy metals. These metals and metalloids predominate in the environment mainly in the form of dust particles (Dartan et al., 2015; Zhong- min et al., 2018; Siyue et al., 2018). Soil contamination with heavy metals by aerial technogenic contamination has caused concern because of the risk elements difficult to decompose and migrate into the human body through food chains (Mohmand et al., 2015; Wei et al., 2009; Shuanxi et al., 2017 ). Some works are also devoted to the problems of forecasting pollution levels of atmospheric air (Harmens et al., 2016; Stravinskienè, 2011; Steinnes et al., 1997), who carried out research on the basis of connec- 
tion of high levels of concentrations of pollutants with climatic conditions (Alloway, 2012; Haiyan \& Stuanes, 2003; Imperato et al., 2003). The estimation of aerotechnogenic contamination by methods of mathematical modeling was carried out in scientific publications (Hsu et al., 2006; AlKhashman, 2004; Shmandiy \& Gurets, 2015). At present, the problem of atmospheric air pollution is highlighted in works carried out using various methods and approaches, the latest modeling methods and geoinformation systems. For the conducting of the research industrial agglomerations or industrial regions are usually selected (Biliaiev \& Kharytonov, 2011; Babiy et al., 2003; Shupranova et al., 2014; Romanchuck et al., 2017b), or individual agglomerations or branches of industry are in focus (Kharytonov et al., 2015; Kharytonov et al., 2017). An important aspect is the influence of climatic conditions on the migration and distribution of pollutants in the environment.

Most current issues of air pollution are stressed in statistical information sources only, while there are no scientific literature sources dealing with the research of the industrial degradation of cultivated land on the territory of small settlements (Top management statistics in Zhytomyr region, 2010-2018). For example, the background contamination within these places is not a concern, however, despite high concentration of such enterprises on a small area, the consideration of this question in the light of all-city background values should be considered as uninformative.

In view of the fact that the formation of background concentrations of pollutants is influenced not only by the parameters of the sources of pollution, but also by the meteorological conditions, a number of scientific works was devoted to this problem. Some scientists have calculated the potential of air pollution on the territory of Ukraine, as well as the meteorological possibilities of the atmosphere for self-cleaning on the examples of different industrial areas (Kunah et al., 2018; Romanchuck et al., 2017a, Hulisz et al., 2011, Zymaroieva et al., 2019). Weather plays a role in most of these components, usually resulting in higher emissions at lower temperatures (Vreca, et al., 2001).

The most dangerous of all the compounds occurring in the environment in the gaseous state, are sulfur dioxide, nitrogen dioxide, heavy metals in the form of coarse and fine dust particles. These compounds can be oxidized in heterogeneous and homogeneous ways after occurring in the environment through adsorption in aqueous masses of clouds, fogs, and rains. The negative influence of the gas-dust air composition near the emission sources, which worsens the ecological state of all living components of landscapes, is accumulated in plants and migrates through food chains to animal and human organisms (Czaja et al., 2015; Ceynowa-Giełdon et al., 2016).

One of the most hazardous components of aerotechnogenic pollution due to the activity of industrial enterprises are coarse and fine dust containing heavy metals and radioactive particles. It is this component that causes the increase of phytotoxicity of the soil (Romanchuk et al., 2018, Fedoniuk et al., 2019).

Therefore, the main goal of this study was to determine the content of heavy metals in cultivated land as a result of airborn technogenic contamination, and the features of their lateral migration in soils.

\section{Material and methods}

The investigation of airborn technogenic pollution of agroecosystems was carried out on the example of the industrial facilities of the eastern part of the territory of Zhytomyr. The surface of theadjoining landscape territory is undulated with a general decrease to the North and North-East (from $500 \mathrm{~m}$ to $300 \mathrm{~m}$ and lower). Accordingly, landforms resulting from the destruction of rocks, such as highlands, hills, rocks with steep slopes is replaced by a plain with a slight variation of heights and the presence of microbasins.

The location of observation points was carried out at various distances (100-2000 m) from the source of pollution in the directions of prevailing winds. Survey areas were selected taking into account the landscape and the landscape-geochemical structure. The first route is laid in the direction of the prevailing northwestern wind, that is, the south-eastern part of the territory of the emission source. Here, light-loamy brunizems on loess loam $\left(\mathrm{pH}_{\mathrm{KCl}}\right.$ 5.8-6.1, humus content 2.1-2.85\%) prevail. The second direction is laid in the eastern direction, in this direction dominate podzolized light-loamy brunizems on loess loam $\left(\mathrm{pH}_{\mathrm{KCl}} 6.0\right.$, humus content $2.23-2.56 \%$ ). The third direction is to the North-East from the source of man-made emissions, here prevails podzolized light-loamy phaeozems on loess loam with $\mathrm{pH}_{\mathrm{H} 2 \mathrm{O}} 6.2$ and humus content of $2.2-2.8 \%$. In this direction, the winds do not blow so much as they do in the south-eastern and northern directions, but this area is located between the areas of increased man-caused emissions, and can be subjected to frequent technogenic pollution due to the movement of surface runoff. The fourth direction is to the north from the source of anthropogenic emission, here prevail podzolized light-loamy phaeozems on loess loam with the $\mathrm{pH}_{\mathrm{H} 2 \mathrm{O}}$ of 7.2 and the content of humus of $2.5-2.8 \%$.

Samples were taken according to the geospatial catena in 20 sites -5 points in 4 directions from the Eastern industrial facilities. The soil type was determined by evaluating soil profiles. All soil samples were collected from the humus topsoil (0-20 cm thick) using the "envelope" method .

Moving forms of $\mathrm{Mn}, \mathrm{Zn}, \mathrm{Pb}$ and $\mathrm{Cu}$ in the soil were determined in a buffer ammonium acetate extract with the $\mathrm{pH}$ of 4.8 by atomic absorption spectrophotometry. 
The atomic absorption determination of the active forms of heavy metals was determined in the acetylene-air flame in the laboratory of the department of instrumentallaboratory control of the State Ecological Inspectorate in Zhytomyr region in accordance with the methodology (DSTU 4770.1-9: 2007).

It would be good to note here that you compare data on heavy metals with their MPC (maximum permissible concentrations).

According to 15 hydrometeorological stations in Zhytomyr region, the stability of the wind was calculated on the stations, the wind force and direction were recorded, and the wind-streams scattering ellipses were constructed. The Atmas dust analyzer and the digital mobile laboratory Einstein $^{\mathrm{TM}}$ LabMate+ with a set of sensors for determining the concentration of gases and dust (the range of the mass concentration of dust from 0.1 to $150 \mathrm{mg} \cdot \mathrm{m}^{-3}$ ) were used to estimate airborn pollution the data of express and automatic control methods using.

In the aerotechnogenic transfer of pollutants the key position is taken by the characteristics of wind streams. In the winter months on the territory of the city of Zhytomyr it is usually cloudy, the winds are characterized by significant velocities - approximately at the level of 4.5 to 25 and more $\mathrm{m} \cdot \mathrm{s}^{-1}$, in January, the lowest temperatures and frequent inversions are noted. In general, for this territory, the presence of weak winds is typical, and circulation flows in the atmosphere do not cause the velocity of winds over $15 \mathrm{~m} \cdot \mathrm{s}^{-1}$. The most unfavorable areas of the Eastern industrial facilities in Zhytomyr are windless periods with a wind force of no more than $1 \mathrm{~m} \cdot \mathrm{s}^{-1}$, that is, during periods of surface temperature inversions, which hinders the vertical migration of air masses. Pollutants in the form of particles suspended in air accumulate in the surface layer for a long period of time, and in combination with low wind speeds, they can cause excessive contamination of adjacent sources of agricultural landscapes. Thus, the geological and geomorphological and natural-climatic parameters of the research area are characterized by significant variability of temperature conditions, wetting of the territory, wind parameters, which causes an increase in the accumulation, migration and dispersion of pollutants, and should be taken into account when calculating the levels of pollution of cultivated land.
Zhytomyr Oblast does not belong to the territory of excessive anthropogenic pressure, but in the period from 2015 to 2018 the index of industrial production increases on average by $110.3 \%$ annually; the fastest growth is noted in the mining and processing industries. The industrial production of the region in terms of growth rate takes the 1st place among other Ukrainian regions (109.8\% in 2015).

One of such problem areas requiring special attention is the so-called «Eastern industrial facilities» in Zhytomyr, within which there are about 45 industrial enterprises of food, light, chemical, metallurgical, machine-building, production of other non-metallic mineral products and other industries. Such a high concentration of multi-directional industrial enterprises on a small area inevitably affects the state of the surrounding ecosystems.

In 2015, from industrial enterprises on this territory contaminants totaled 8.98 thousand tons. A part of these compounds precipitates on the surface of the soil and reacts with heavy metals, causing secondary pollution of the soil.

\section{Results and discussion}

There are 85 stationary sources of pollutant emissions on the territory of the research facilities, and the main contribution to atmospheric pollution is made by rotary kilns about 4600 tons of inorganic dust per year. Somewhat less than $60 \%$ of dust is recycled by dust treatment plants. Technological treatment of raw materials involves the formation of dust containing high concentrations of $\mathrm{Mn}, \mathrm{Zn}$, $\mathrm{Pb}, \mathrm{Cd}$ and $\mathrm{Cu}$ (Table 1). It has been calculated that during the last decade emissions of heavy metals with non-localized dust were: $\mathrm{Mn}-33158, \mathrm{Zn}-3687, \mathrm{Ni}-4604, \mathrm{Cu}-$ $7736, \mathrm{Cr}-42364 \mathrm{~kg}$. During the period of active plants vegetation (April - September), 62\% of annual emissions of heavy metals amounted to $5753 \mathrm{~kg}$ (Table 1).

The investigated area of rectangular shape has an area of 1475.189 hectares. An interpolation using the method of IDW (inverse distance weighting) on the territory within the sampling points has allowed to select areas with different contents (Fig. 1). The largest content $>3$... received on the area of 60.714 ha, which is $4.12 \%$ of the territory. The content from 2 to $3 \ldots$ is observed on an area of 911.927 hectares, $61.82 \%$. Low pollution from $1-2 \ldots$ is observed

Table 1 . The content of heavy metals in dust, $\mathrm{M} \pm \mathrm{m}, \mathrm{mg} \cdot \mathrm{kg}^{-1}$

\begin{tabular}{|l|c|c|c|c|c|c|c|c|}
\hline \multirow{2}{*}{\multicolumn{1}{|c|}{ Type of dust components }} & \multicolumn{9}{|c|}{ Cations } \\
\cline { 2 - 9 } & $\mathbf{M n}$ & $\mathbf{Z n}$ & $\mathbf{P b}$ & $\mathbf{C d}$ & $\mathbf{N i}$ & Nî̀ & $\mathbf{C u}$ & $\mathbf{C r}$ \\
\hline $\begin{array}{l}\text { Non-localized } \\
\text { inorganic dust }(\mathrm{n}=5)\end{array}$ & $1349 \pm 65$ & $163 \pm 25$ & $31 \pm 5$ & $3 \pm 0.3$ & $235 \pm 21$ & $15 \pm 2$ & $387 \pm 17$ & $1456 \pm 98$ \\
\hline
\end{tabular}


on the area of 487.010 hectares, $33.01 \%$. And low content $<1 \ldots-$ on the area of 15.538 hectares, i.e. $1.05 \%$.

About $20 \%$ of the examined air samples showed a 4-5-times increase in MPC. The biggest part of them was marked in the range up to $400 \mathrm{~m}$, slightly less than a quarter exceeded MPC by 2-3 times. The largest part of the points - about $40 \%$ - was at the level from 1 to 2 of MPC, such indicators were observed almost on the whole distance from the emission source studied. Normal- ization of the air state in this direction was noticed only at a distance of $1000 \mathrm{~m}$ from the source of emission. Between the content of dust in the air due to the movement of the southern wind and the distance from the source of emission, a correlation is established $(r=-0.5397)$ (Fig. 2).

At a distance of $250 \mathrm{~m}$ from the source of emission, dust pollution reduced due to scattering by the wind, the range of variation of air samples for dust content in the air showed an excess of MPC by 2.8-4.2 times. The median

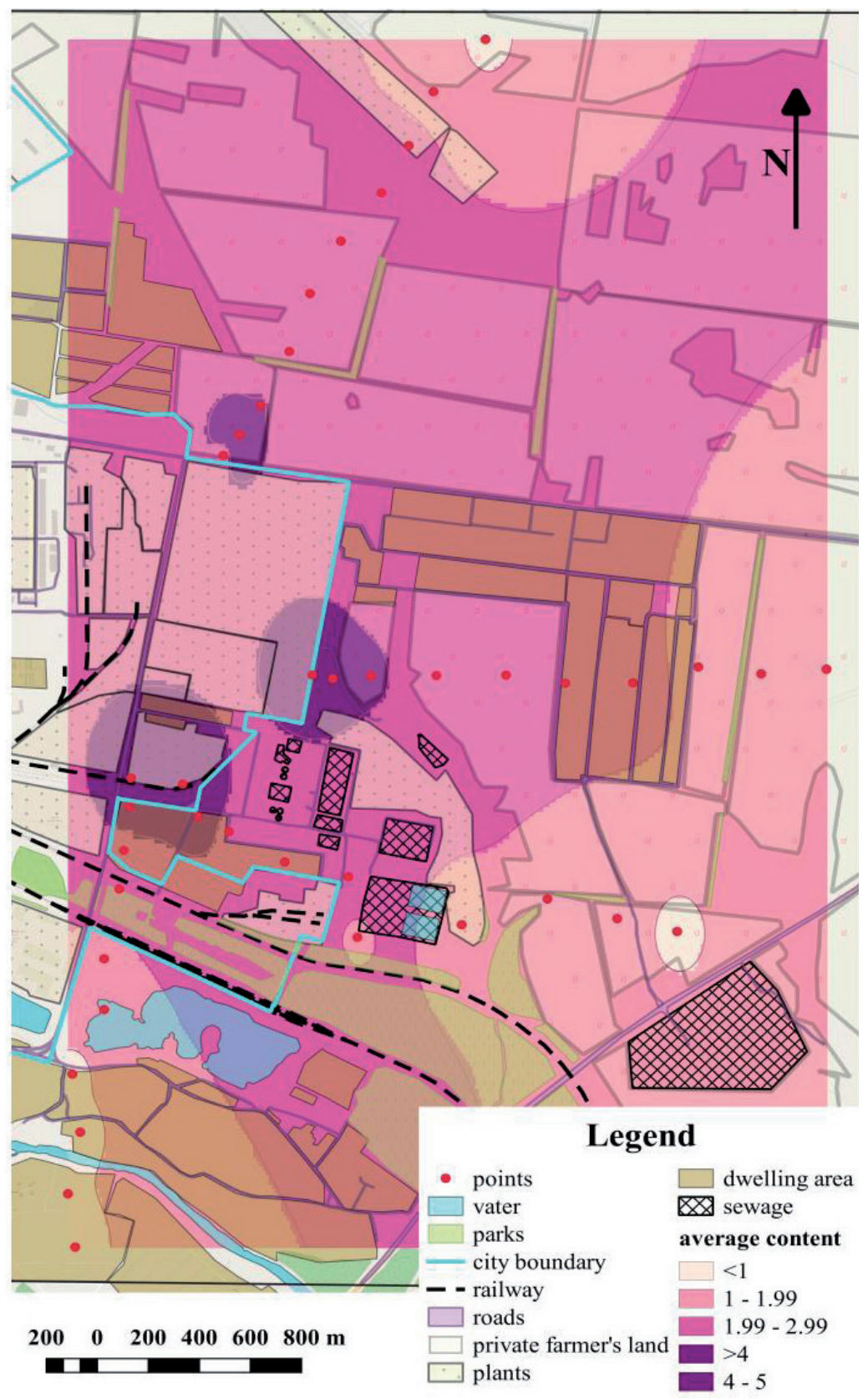

Figure 1. Interpolation by IDW method of aerotechnogenic pollution of the territory of the eastern industrial plant of Zhytomyr (Ukraine) 
of multiplicity of MPC for such a distance is 3.7769. With further displacement from the source of pollution emission, the pollution is reduced, but the level of pollution remains high at a distance of $500 \mathrm{~m}$ and $750 \mathrm{~m}$. In this range, the variation of the indicators of the MPC excess is quite significant from 1.5 to 4 times. The medians of multiplicity of MPC for this were 3.2201 and 2.6414 for distances of 500 and $750 \mathrm{~m}$, respectively. From a distance of 1000 $\mathrm{m}$, a gradual stabilization of the state of the air begins, with variation ranges for distances of $1-1.75 \mathrm{~km}$, which remain quite significant - from 0.2 to 2.5 MPC. Meanwhile, the medians remained higher than MPC - 2.4388 (for $1000 \mathrm{~m}$ ), 2.1272 (for $1250 \mathrm{~m}$ ), 1.846 (for $1500 \mathrm{~m}$ ) and 1.5324 (for $1750 \mathrm{~m}$ ). Only at a distance of $2000 \mathrm{~m}$ the situation can be considered as normal, ranges of variations of the values of multiplicity of MPC were from 0.2 to 1 , and the median was at the level of 0.9415 .

The average annual frequency of the north-western wind in this direction is $12 \%$, and for this area these are the most frequent wind flows. In this direction 1400 measurements were made. Samples of dust pollution in the direction of the north-western wind showed that the MPC content of dust in the air exceeded by 4-5 times, such indicators were recorded at a distance of $400 \mathrm{~m}$. Most air samples that exceeded MPC by 2-3 times, as in the previous direction, did not go beyond the $1.5 \mathrm{~km}$ zone, with $14 \%$ of the samples having values ranging from 3 to $4 \mathrm{MPCs}$, and $30 \%$ of the samples in the range of $2-3$ MPCs. Most of the research points had the values of dust contamination, which slightly exceeded $1 \mathrm{MPC}-36 \%$, but it should be noted that their number increased as far away from the source of pollution beyond the 1-km zone. There were only $7 \%$ of those that did not exceed MPC, but their presence was also noticed only outside the 1-km zone.

A less frequent western wind (10\%) causes a similar length of propagation of dust masses. Extremes exceeded MPC (less than 4) only at a distance of not more than $500 \mathrm{~m}$ from the source of emission. Here, the maximum pollution figures (4.85 MPC) were noted, however, the excess of MPC by 3-4 times was noted at a distance of up to $1.5 \mathrm{~km}$, and by $1-2$ times - up to $2 \mathrm{~km}$. Stability of dust pollution indicators in this direction became noticeable not earlier than $1.5-2 \mathrm{~km}$, although most of the measurements there showed excess of the established MPCs. The relative majority of dust pollution indicators were marked at the border of the $2-\mathrm{km}$ zone.

In the north-eastern direction, the winds intensity is not so strong, but the territory adjacent to the eastern industrial facilities in this direction is represented by fertile dark-gray podzolized loose-loamy soils and podzolized chernozems. The frequency of winds within this direction is at the level of $5 \%$, however, the transfer of dust masses is also rather intense due to the scattering of flows caused by the western and southern winds.

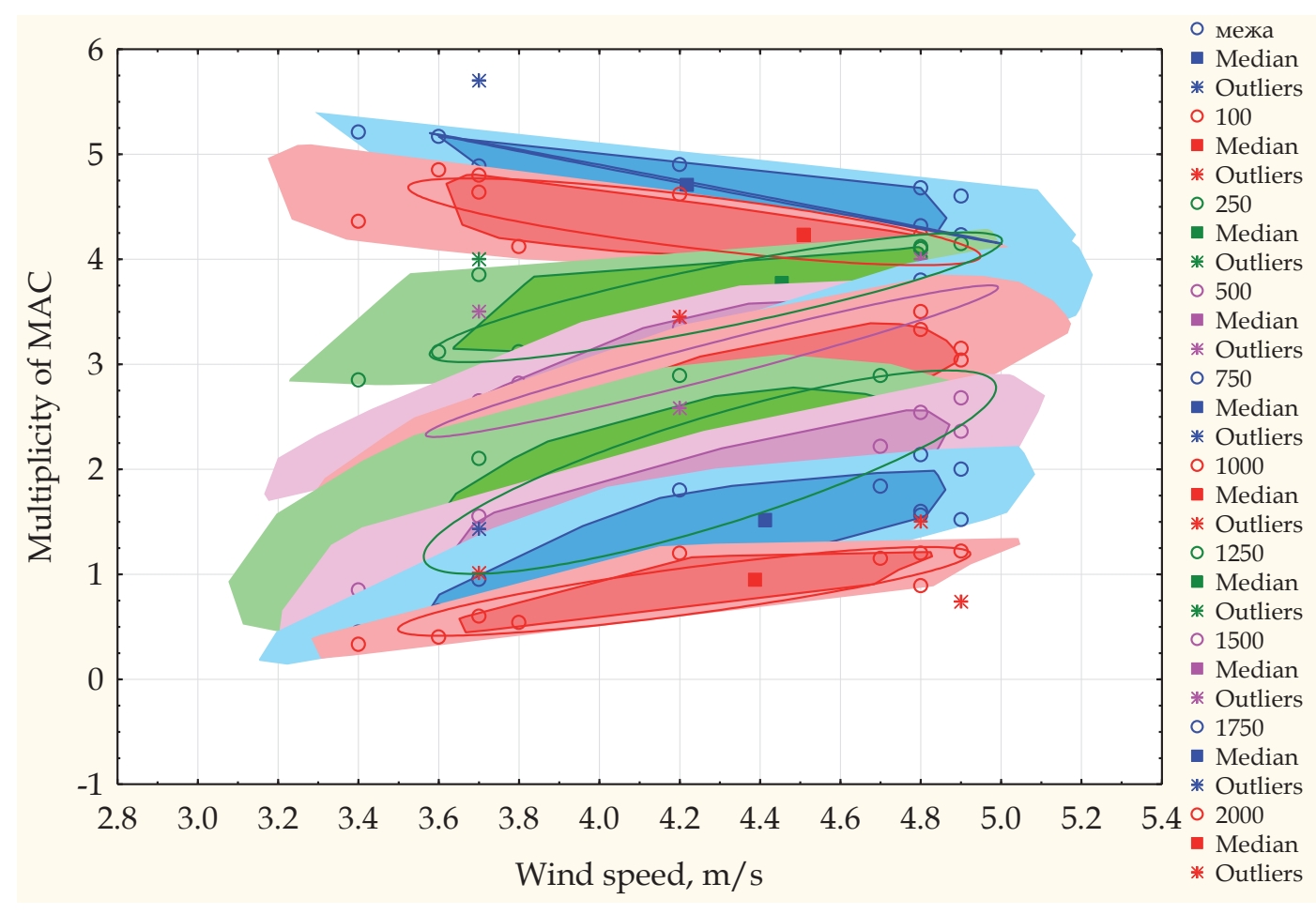

Figure 2. Dependence of dust pollution on wind speed 
In this part of the culticated lands, dust masses in concentrations exceeding 5 MPCs are formed in the immediate proximity to the industrial facilities - up to $400 \mathrm{~m}$, however, their number was $7 \%$ of the total number of samples. $100 \%$ of the points having MPC above 2 were recorded at a distance of $600 \mathrm{~m}$ from the source of emission. Nearly $30 \%$ of analyzed air samples for dust content exceeded the norms of a little more than 1; such tests were noticed even at a distance of $2.2 \mathrm{~km}$. It should be noted that the largest proportion of samples still conformed to the norms $-36 \%$, they were noticed at a distance not closer than $800 \mathrm{~m}$ from the source of emission. That is, it should be noted that even at a slight wind speed, the transfer of dust particles occurs at a distance of not less than $1000 \mathrm{~m}$, which causes higher levels of air pollution by this indicator.

The conducted research showed a shift in the distribution of dust pollution from the frequency and direction of prevailing winds (Fig. 3). The smallest frequency of occurrence of excess of critical points in the direction of the south-western wind, which is characterized by the least frequency for the given area (Location = 1.7967; Scale $=1.3229$ ). The strongest dispersion of dust in the distance from the source of emission is noted for the most intense and frequent north-western wind (Location $=$ 2.3992; Scale $=1.1021$ ). When scattering of dust with this wind, the appearance of critical points exceeds MPC by 0.6 points, with the eastern one - by 0.51 points and the southern one - by 0.36 points.

As noted in the investigations of many scholars, the dispersion of pollutants, including dust, to a large extent depends not only on frequency but also on the strength of the wind. When increasing the wind, the medians of the multiplicity of MPC were shifted on all the studied areas.

Having analyzed all the data for all directions of emission, it was determined that the distribution of dust masses occurs in winds with a force of 3.2 to $5.2 \mathrm{~m} \cdot \mathrm{s}^{-1}$. At the edge of the "eastern industrial facilities - agrolandscape" the level of dust pollution varied in the range from 3.8 to $5.4 \mathrm{MPC}$. The median of multiplicity of MPC for such a distance is 4.7102 . As far as the distance from the industrial facility is 100 $\mathrm{m}$, the air pollution remains at practically the same level as at the boundary of the emission source, with values recorded exceeding MPC by 3.8-5.1 times. The median of multiplicity of MPC for the 100-m distance is 4.2376. Dense correlation connections are established between the wind speed and the excesses of MPC at all intervals of distances from the emission source (Table 2).

The territory adjacent to the Eastern industrial facilities is in agricultural use, along with the territory under

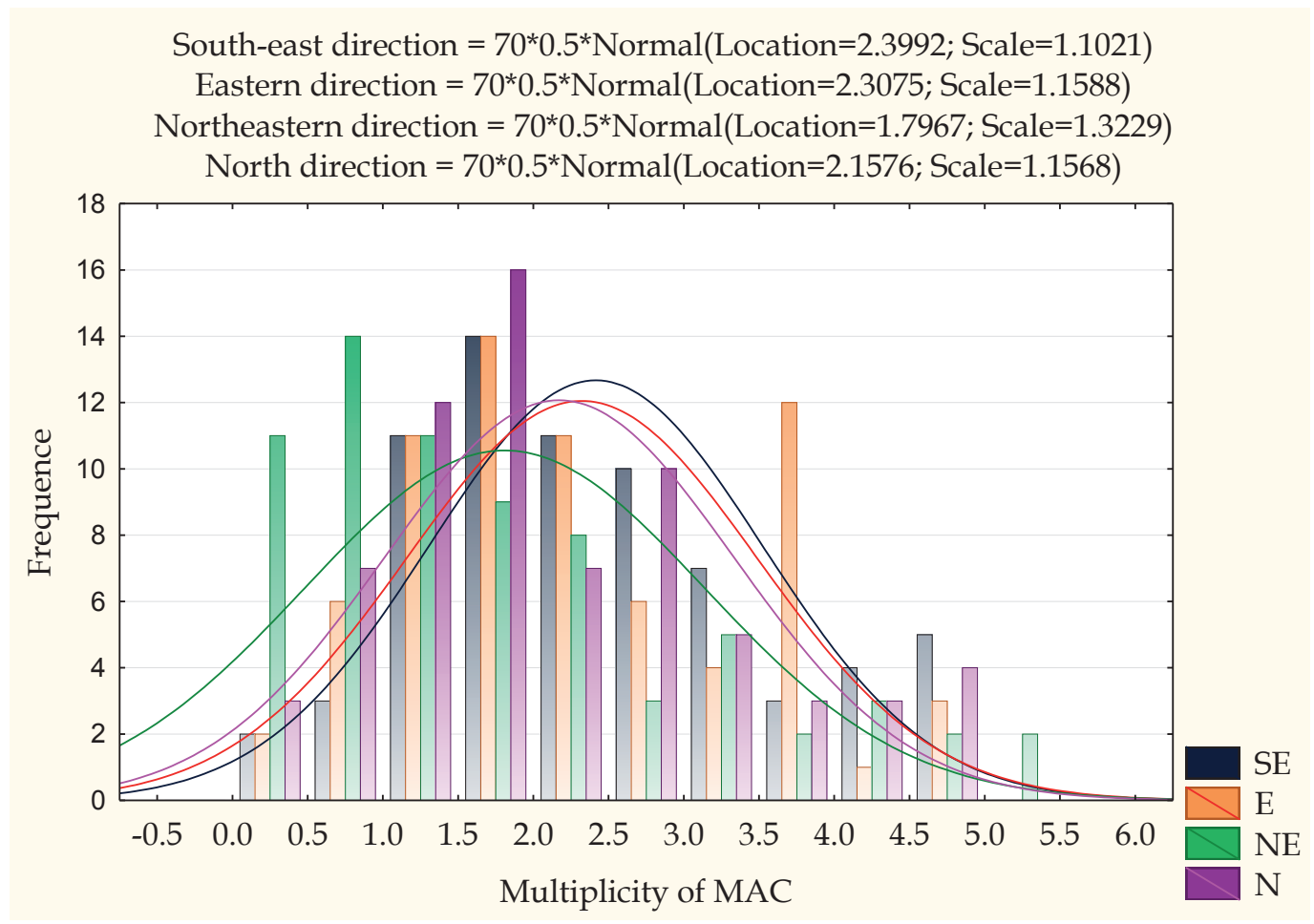

Figure 3. Histograms of the distribution of critical values of the MPC excess under the influence of the prevailing winds of the eastern industrial facilities 
industrial enterprises there are a house, a bypass road. The most widespread chernozems here are podzolized medium loamy and dark-gray podzolized medium loamy soils, characterized by a weakly acidic or neutral reaction of the soil solution. This causes the accumulation of heavy metal cations, which is associated with a decrease in their mobility when absorbed by the soil-wiping complex.

The medium loamy mechanical composition of podzolized chernozems and dark-gray podzolized soils causes high cation exchange capacity, that is, the increased risk of absorption of heavy metal cations by soil solution.

The mechanical composition of the technozem soils was analyzed in 4 directions of the prevailing winds at different distances from the source of pollution - from $5 \mathrm{~m}$ to $1000 \mathrm{~m}$. The soil in accordance with the soil cut was defined as podzolized chernozem and gray forest podzolized chernozem, with the distribution of soil fractions at the control point: $1-0.25 \mathrm{~mm}-37.4 \%, 0.25-$ $0.05 \mathrm{~mm}-30.5 \%, 0.05-0.01 \mathrm{~mm}-22.6,0.01-0.005$ $\mathrm{mm}-2.8 \%, 0.005-0.001 \mathrm{~mm}-3.9 \%$, less than 0.001 $\mathrm{mm}-2.8 \%$.

For technozems in the immediate proximity to the industrial facilities $-5 \mathrm{~m}-$ a light granulometric composition with a predominance of large-fractional dust was noted $-0.05-0.01 \mathrm{~mm}-23.41 \%$ and of fine sandstone dust $-0.25-0.05 \mathrm{~mm}-39.5 \%$ and of a large fraction $-1-0.25 \mathrm{~mm}-20.6 \%$. The sludge content is slightly less than $10 \%$, a significant proportion of physical sand and clay is $-0.01 \mathrm{~mm}-21.23 \mathrm{~mm}$. In this part, the granulometric composition of the soil can be characterized as light-loamy big-dust and fine-grained (Fig. 4).
As far as the source of pollution to 50-200 m gradually reduced the content of large and small sand fraction by 1.98-5.27 times, respectively. Accordingly, the proportion of the mold fraction and physical sand and clay was almost doubled. This led to the displacement of mediumloamy soils with predominance of fine sand particles of $30.15-18.56 \%$ and a large dust of $43.50-30.52 \%$. Such granulometric composition has a characteristic medium-loamy fine-grained large-grained.

The proportion of large and fine sand increases again from 18.56 to $29.51 \%$ and from 30.15 to $45.15 \%$ with a further distance from the objects of pollution by 250 and more meters, respectively. The content of the smallest fractions - physical sand and clay and small silt decreases and the soil acquires the character of fine-grained sand.

Equidistant in degraded sod-podzolized soils in various directions from the industrial facilities, changes in soil texture are noted. In the vicinity - 50-100 m there is a predominance of heavy fractions. The increase in the fraction of large and dust is observed at intervals up to $250 \mathrm{~m}$, the average - up to $400 \mathrm{~m}$, the fine - up to 600 $\mathrm{m}$, the content of the smallest fractions increases from 50 and is kept high up to $750 \mathrm{~m}$.

These studies show that, as far as the distance from the industrial facilities is concerned, not only the granulometric composition, but also the specific surface of the soil particles, as well as their ability to absorb, change. At the same time, the lowest humidity of a monomolecular layer of soil particles is characteristic of technozem, remote from 750-1000 $\mathrm{m}-2.3-2.99$, and the specific surface of soil particles is $70.9-89.5 \mathrm{~m}^{2} \cdot \mathrm{g}^{-1}$. The highest humidity of the monomolecular layer was observed at a dis-

Table 2. Linear dependencies of aerotechnogenic dust pollution depending on the wind speed

\begin{tabular}{|c|c|c|c|c|c|}
\hline $\begin{array}{c}\text { Distant from the } \\
\text { source of emission }\end{array}$ & Equation of dependence & $\begin{array}{c}\text { Determination } \\
\text { coefficient, } \mathbf{r}\end{array}$ & Reliability, $\mathbf{p}$ & $\begin{array}{c}\text { Coefficient } \\
\text { of correlation } \mathbf{r}^{2}\end{array}$ & $\begin{array}{c}\text { Density } \\
\text { of relationship }\end{array}$ \\
\hline limit & $\mathrm{y}=7.782-0.7307 * \mathrm{x}$ & -0.7369 & 0.0063 & 0.5430 & High \\
\hline 100 & $\mathrm{y}=6.0633-0.4095 * \mathrm{x}$ & -0.7181 & 0.0085 & 0.5157 & High \\
\hline 250 & $\mathrm{y}=1.5345+0.4914 * \mathrm{x}$ & 0.6065 & 0.0365 & 0.3678 & Average \\
\hline 500 & $\mathrm{y}=-0.3576+0.8205 * \mathrm{x}$ & 0.8022 & 0.0017 & 0.6436 & High \\
\hline 750 & $\mathrm{y}=-1.991+1.111 * \mathrm{x}$ & 0.9003 & 0.00007 & 0.8106 & High \\
\hline 1000 & $\mathrm{y}=-2.4612+1.1533 * \mathrm{x}$ & 0.7968 & 0.0019 & 0.6349 & High \\
\hline 1250 & $\mathrm{y}=-2.0114+0.9319 * \mathrm{x}$ & 0.7545 & 0.0046 & 0.5693 & High \\
\hline 1500 & $\mathrm{y}=-2.8595+1.0806 * \mathrm{x}$ & 0.8453 & 0.0005 & 0.7146 & High \\
\hline 1750 & $\mathrm{y}=-2.1256+0.8177 * \mathrm{x}$ & 0.8277 & 0.0009 & 0.6851 & High \\
\hline 2000 & $\mathrm{y}=-1.0379+0.4529 * \mathrm{x}$ & 0.7217 & 0.0081 & 0.5208 & High \\
\hline
\end{tabular}




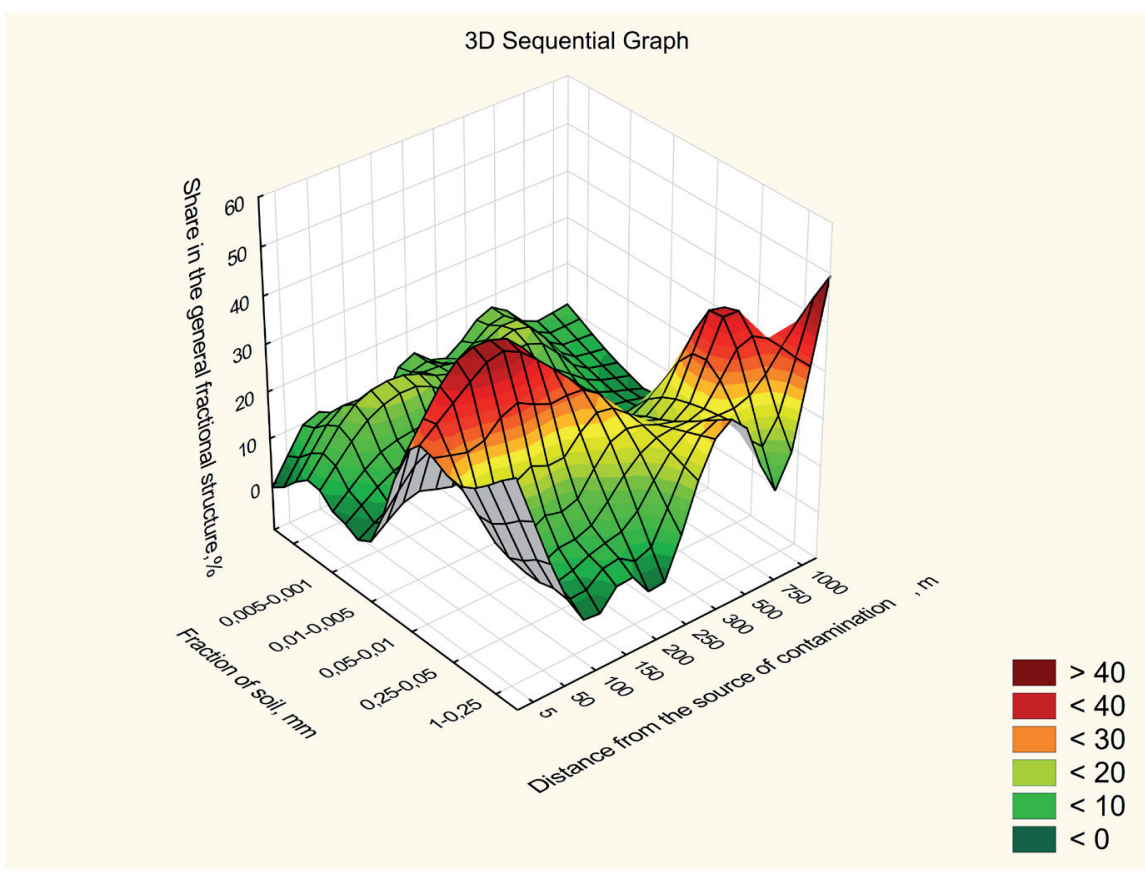

Figure 4. 3D sequential distribution of soil fractions in industrial degraded soils (dark gray podzolized soil)

tance of 50-250 m, where this index was 3.56-6.52\%, and the specific surface of soil particles was 2 or more times higher, in comparison with the same indicator of soil on more distant areas (Fig. 5).

Such a composition of technozems near the Eastern industrial facilities indicates high permeability to the soil, poor water-holding and absorption properties, low water resistance and buffering to pollutants, etc. Thus, we can testify to the mosaicity of the upper soil layer by the content of the mineral particle, and, as a result of the redistribution of soil fractions, changes in the humidity regime and accumulation of humus occur.

In order to evaluate the content of active forms of heavy metals in the soil, we used the background values proposed by Prister (1994).

Analysis of the indexes of $\mathrm{Cu}$ content in the zone of influence of the Eastern industrial facilities shows that the level of pollution in the direction of the prevailing north-western wind exceeds levels of soil contamination in other areas of emission. Although it should be noted that the connection between the distance from the source of emission and the concentration of compost in soils is noted on all investigated areas. In this case, close inverse correlation links are noted. This indicates that the settling of dispersed particles containing cooper is most intense in the immediate proximity to the emission source. The highest concentrations of $\mathrm{Cu}$ are marked in the direction of the prevailing winds - the south-eastern and eastern ones.
The histogram of the distribution of the concentrations of active forms of $\mathrm{Cu}$ in the soils of the studied territory showed shift of the distribution curves in the direction of the north-western wind (Fig. 6).

Meanwhile, the median values for the direction of the north-western wind were in the range of 3.7579 , for the less frequent winds these values were lower: for the eastern direction -3.1288 , and for the northern region 2.5692 , it should be noted that the concentration of active forms of $\mathrm{Cu}$ in the north-eastern direction was quite high, although the wind streams are not very frequent here. We associate this fact with the features of relief and the receipt of surface runoff from more polluted areas.

The constructed ellipse of dispersion of $\mathrm{Cu}$ compounds indicates that the most mosaic soil contamination is observed in the south-eastern direction, for example, on the areas with levels of pollution from 1 to $5 \mathrm{MPC}$ can occur within a 1-km distance (Fig. 7). Reduction of the frequency of winds causes the reduction of soil contamination in the eastern direction from 1 to $3 \mathrm{MPC}$. The least mosaic for pollution by cooper were areas of the north-eastern direction, where the maximum predictive values are at the level of 1-2 MPC, approximately the same level of contaminated soil cover in the northern direction.

As shown in Fig. 8, the median of lead contamination in the direction of the most frequent winds was the highest $-1.48 \mathrm{mg} \cdot \mathrm{kg}^{-1}$ in the south-eastern and eastern directions. However, close correlations between the level of soil contamination with lead and the distance from the source 


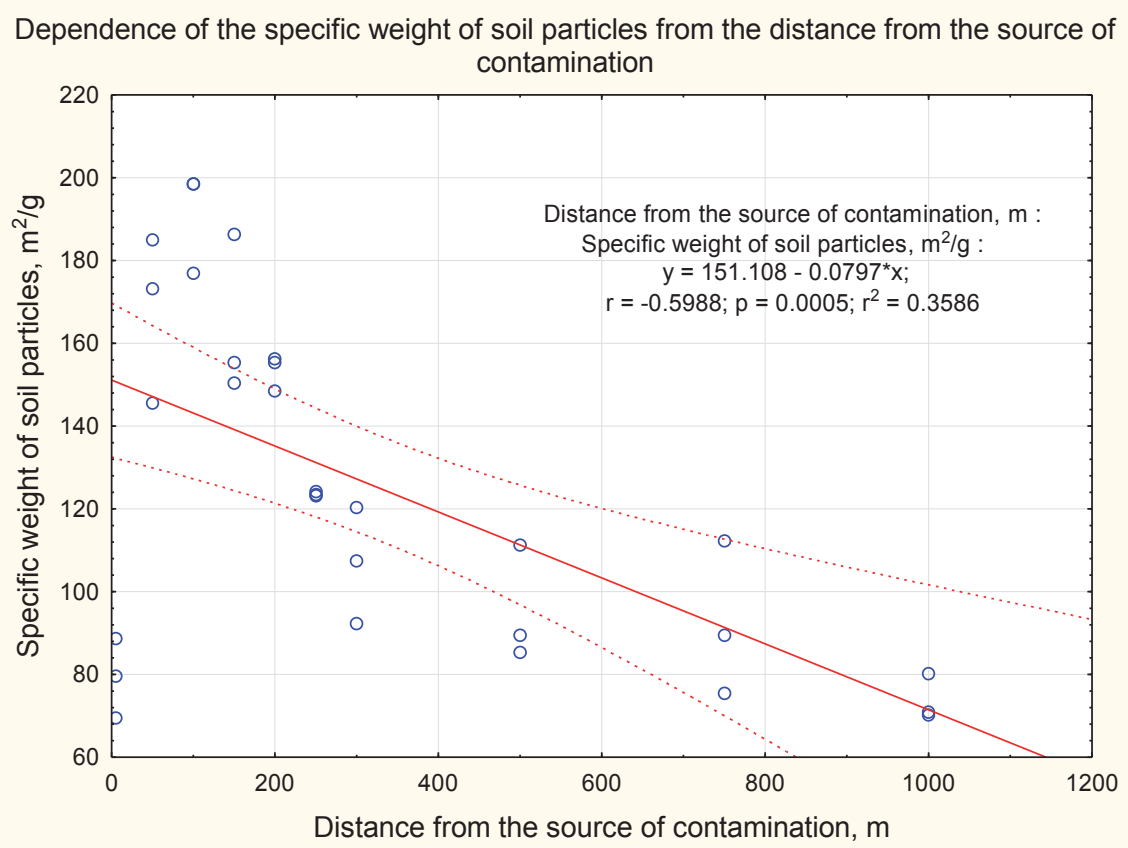

Figure 5. Dependence of the specific weight of soil particles from the distance from the source of contamination

Table 3. Descriptive statistics of data on the accumulation of heavy metals in the soils of the zone of influence of the eastern industrial facilities on the areas of prevailing winds

\begin{tabular}{|c|c|c|c|c|c|c|c|}
\hline Indicator & Direction & $\operatorname{Max} \leq \mathbf{x} \geq \operatorname{Min}$ & Mean & Equation of dependence & StdDev & $\begin{array}{c}\begin{array}{c}\text { Pearson } \\
\text { coef. } \\
\text { of correl., } r\end{array}\end{array}$ & $\begin{array}{c}\text { Statist. } \\
\text { meaning, } \\
\mathbf{P}\end{array}$ \\
\hline \multirow{4}{*}{$\mathrm{Cu}$} & South-East. & $9.46 \leq x \geq 0.44$ & 3.7579 & $\mathrm{y}=5.5595-0.0018 * x$ & 2.2892 & -0.5360 & 0.0000 \\
\hline & East. & $9.11 \leq x \geq 0.34$ & 3.1288 & $y=4.3995-0.0013 * x$ & 1.8399 & -0.4703 & 0.0000 \\
\hline & North-East. & $7.71 \leq x \geq 0.31$ & 2.9152 & $\mathrm{y}=4.2339-0.0013^{*} \mathrm{x}$ & 1.5195 & -0.5910 & 0.0000 \\
\hline & North. & $7.29 \leq x \geq 0.33$ & 2.5473 & $\mathrm{y}=3.9084-0.0014 * x$ & 1.5878 & -0.5838 & 0.0000 \\
\hline \multirow{4}{*}{$\mathrm{Pb}$} & South-East. & $3.30 \leq x \geq 0.14$ & 1.4801 & $y=0.8418+0.0006^{*} x$ & 0.7638 & 0.5692 & 0.00000 \\
\hline & East. & $3.91 \leq x \geq 0.49$ & 1.4817 & $\mathrm{y}=1.3628+0.0001 * \mathrm{x}$ & 0.6137 & 0.1319 & 0.2153 \\
\hline & North-East. & $3.44 \leq x \geq 0.44$ & 1.2956 & $\mathrm{y}=0.8841+0.0004 * x$ & 0.4926 & 0.5690 & 0.00000 \\
\hline & North. & $2.21 \leq \mathrm{x} \geq 0.10$ & 1.2302 & $\mathrm{y}=0.587+0.0006^{*} \mathrm{x}$ & 0.5267 & 0.8318 & 0.0000 \\
\hline \multirow{4}{*}{$\mathrm{Mn}$} & South-East. & $60.93 \leq x \geq 17.81$ & 41.7275 & $\mathrm{y}=30.7707+0.0111 * x$ & 10.4410 & 0.7146 & 0.0000 \\
\hline & East. & $58.36 \leq x \geq 18.48$ & 39.7010 & $y=36.0972+0.0036^{*} x$ & 10.5467 & 0.2327 & 0.0273 \\
\hline & North-East. & $48.17 \leq x \geq 13.11$ & 33.7148 & $y=27.5803+0.0062 * x$ & 7.5928 & 0.5502 & 0.00000 \\
\hline & North. & $51.67 \leq x \geq 16.04$ & 34.9535 & $y=26.2277+0.0088 * x$ & 9.3005 & 0.6389 & 0.0000 \\
\hline \multirow{4}{*}{$\mathrm{Zn}$} & South-East. & $34.09 \leq x \geq 1.84$ & 19.1043 & $y=14.49+0.0047 * x$ & 6.3441 & 0.4964 & 0.00000 \\
\hline & East. & $30.84 \leq x \geq 5.48$ & 18.0913 & $y=12.805+0.0053 * x$ & 6.0254 & 0.5988 & 0.00000 \\
\hline & North-East. & $28.79 \leq x \geq 8.97$ & 16.9309 & $\mathrm{y}=11.2989+0.0057^{*} \mathrm{x}$ & 5.3212 & 0.7224 & 0.0000 \\
\hline & North. & $29.32 \leq x \geq 2.17$ & 18.5500 & $y=14.5548+0.004 * x$ & 5.8436 & 0.4666 & 0.00001 \\
\hline
\end{tabular}




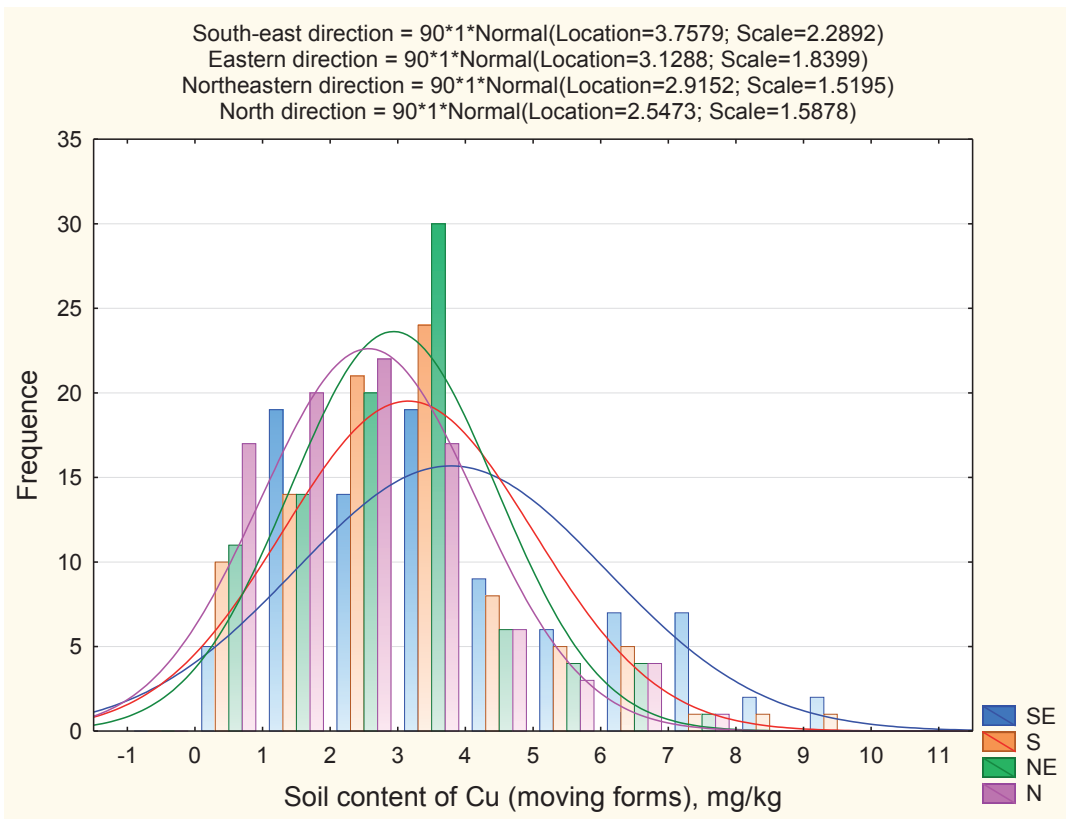

Figure 6. Histogram connected with the Gauss curve, which reflects the variation in the content of active forms of cooper on the areas of prevailing winds
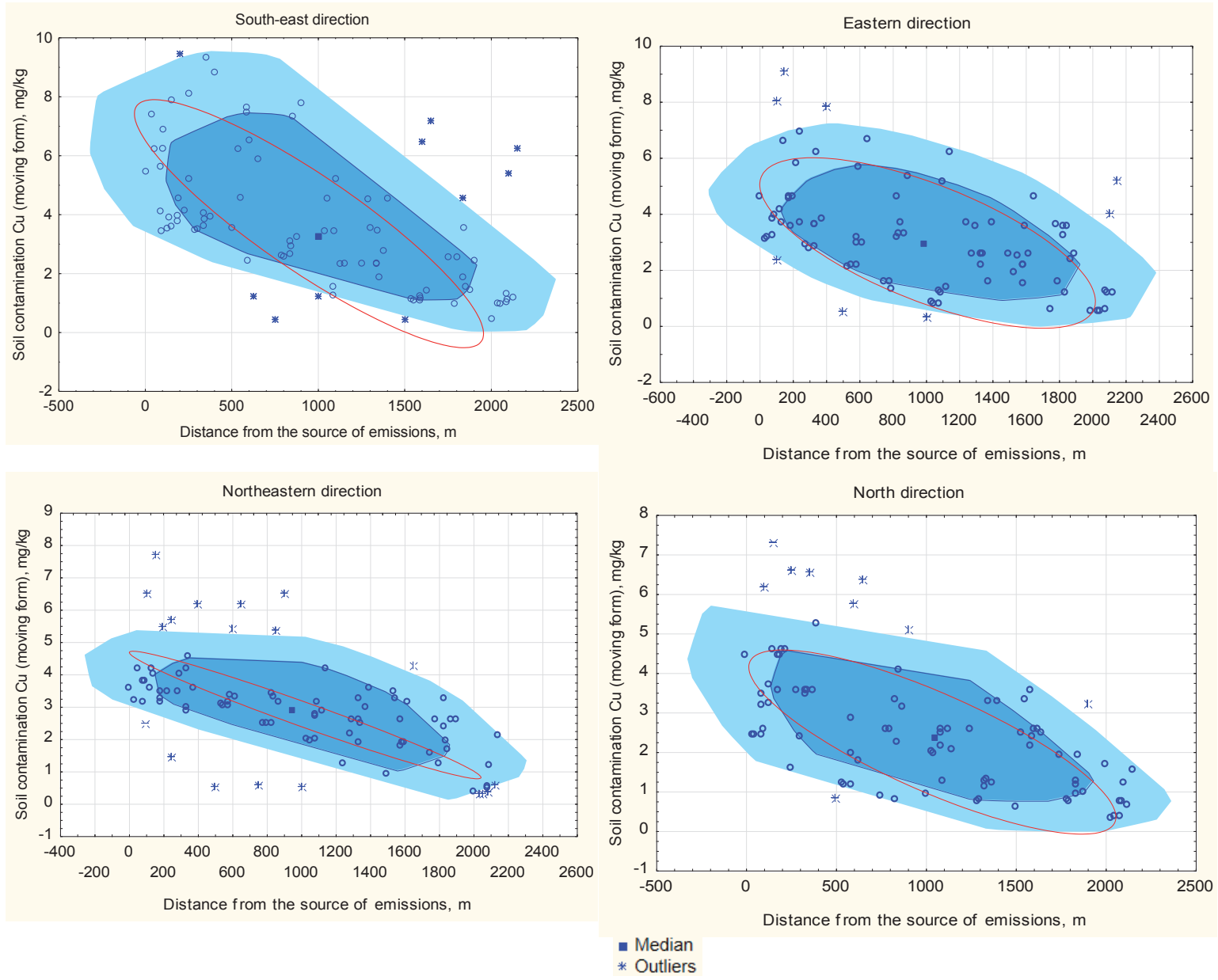

Figure 7. Ellipses of soil pollution by cooper at different distances from the source of emission 


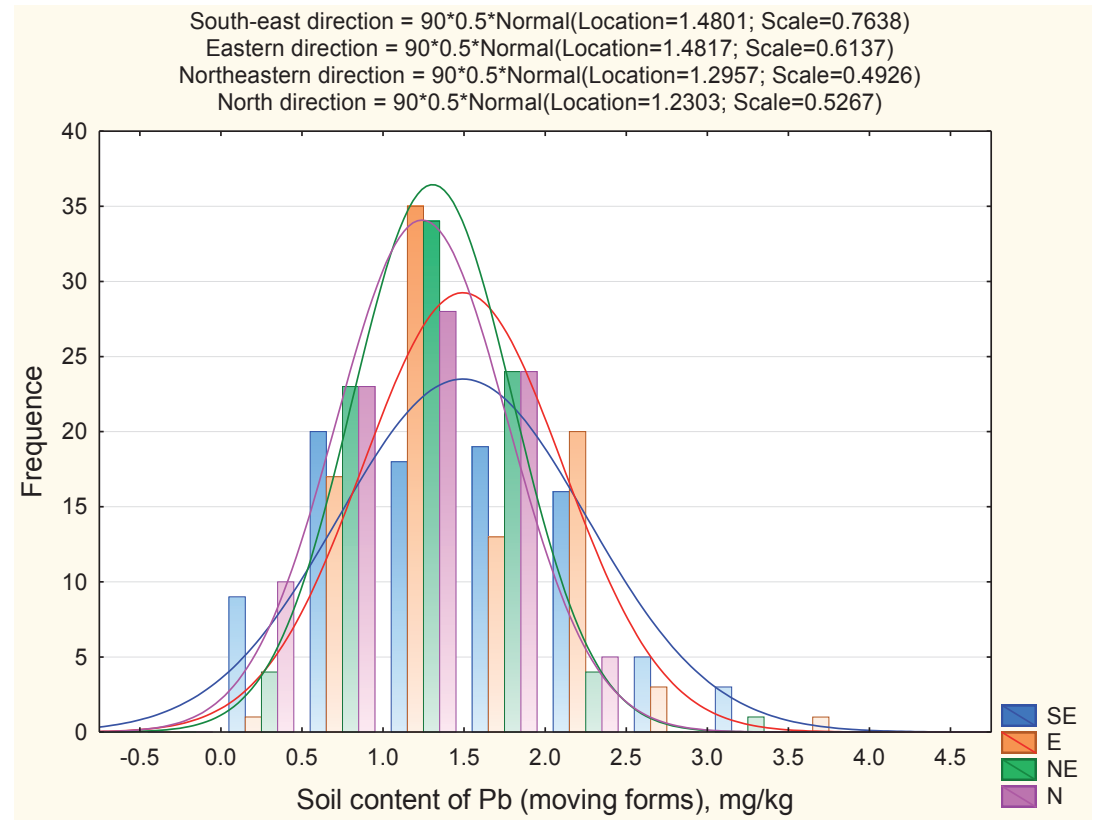

Figure 8. Histogram connected with the Gauss curve, which reflects the variation in the content of the active forms of lead on the areas of the prevailing winds
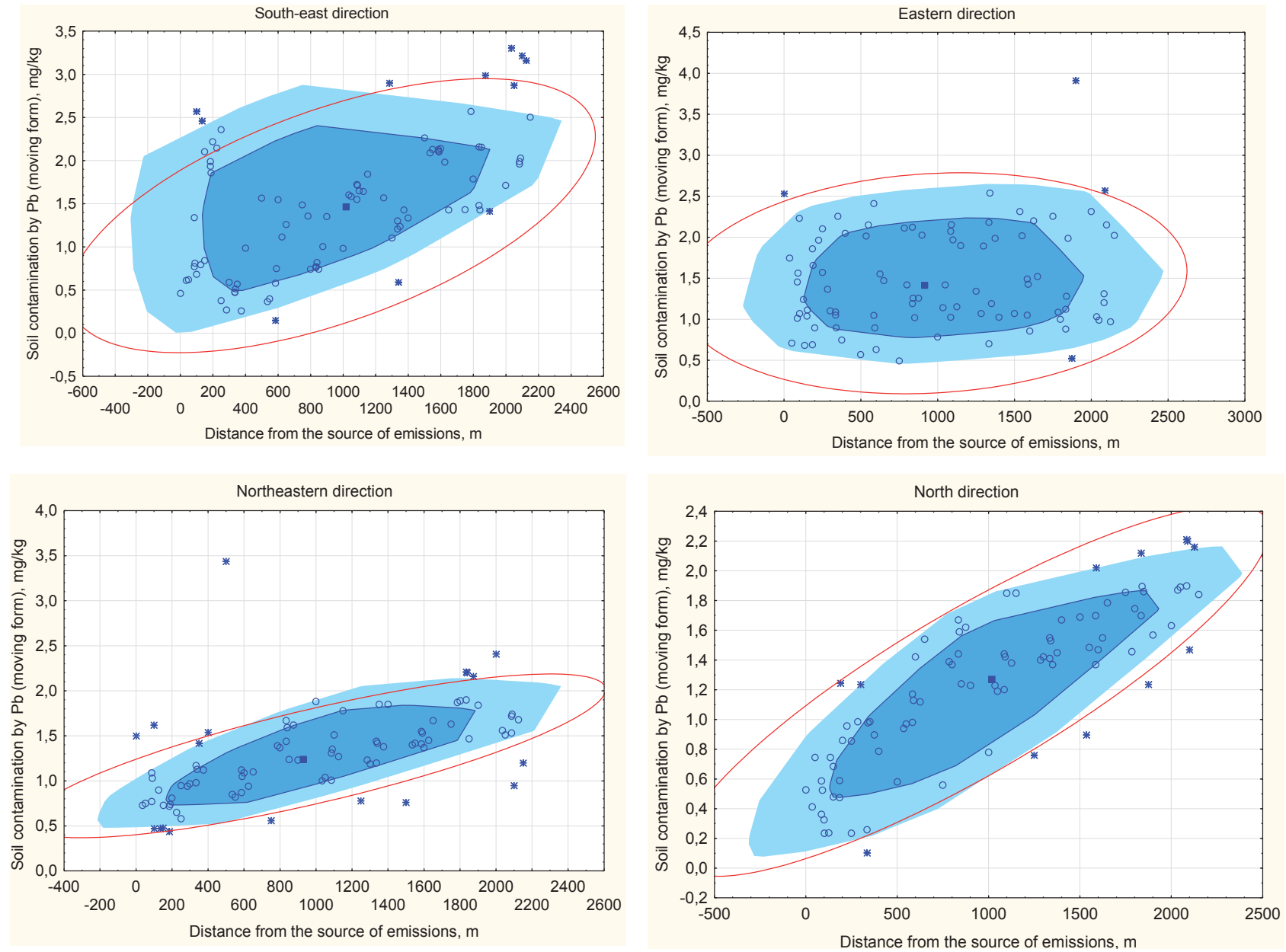

Figure 9. Ellipses of soil contamination by lead at different distances from the source of emission 


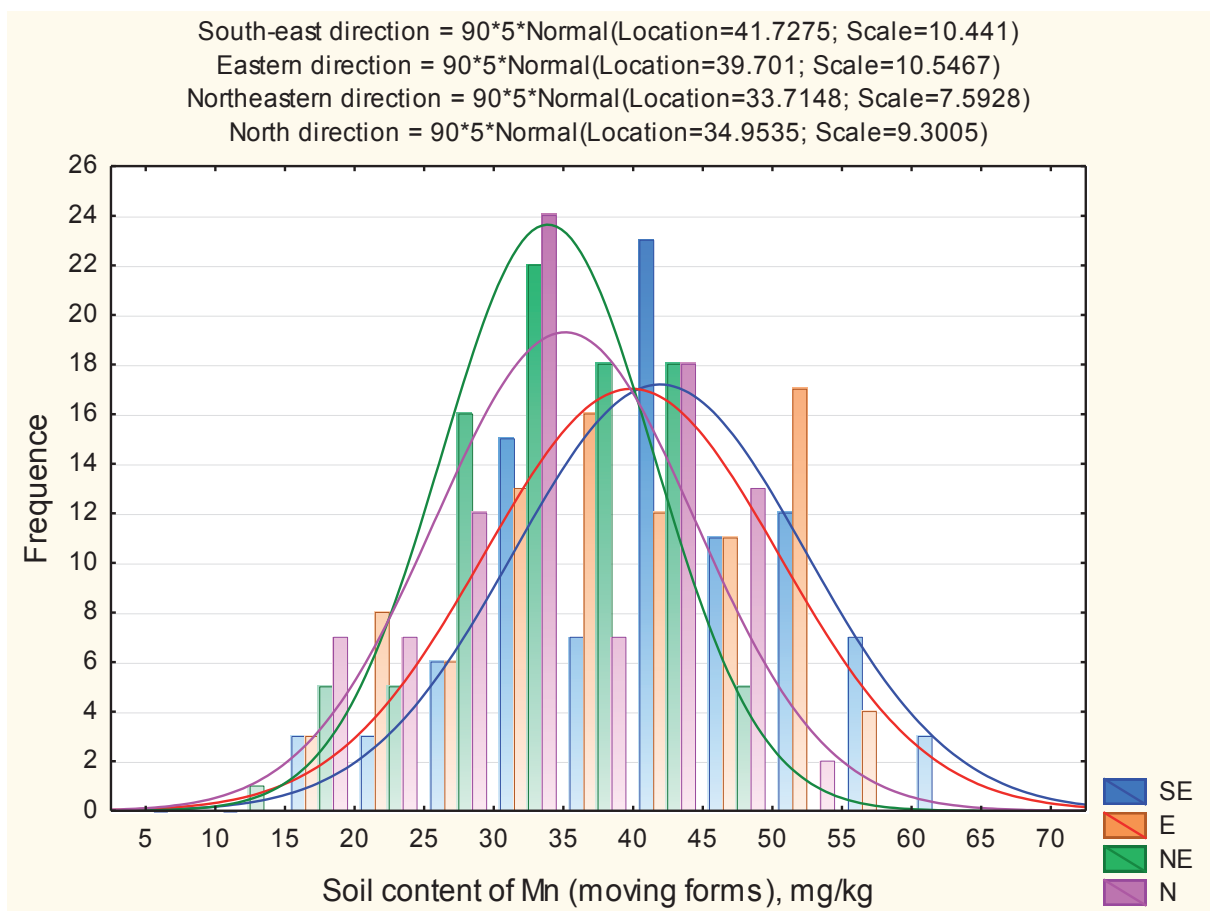

Figure 10. Histogram connected with the Gauss curve, which reflects the variation in the content of the manganese active forms on the areas of the prevailing winds

of emission are noted in all directions, except the eastern one. Gauss's most peaked curve was in the direction of the least-recurring winds - the north-eastern one, indicating the highest stability of the $\mathrm{Pb}$ concentration indicators. The most "flutter" was the "Gauss's bell" in the most critical south-eastern direction.

At the same time, the median values for less frequent winds were lower: for the eastern direction $-1.30 \mathrm{mg} \cdot \mathrm{kg}^{-1}$, and for the northern one $-1.23 \mathrm{mg} \cdot \mathrm{kg}^{-1}$, it should be noted that the concentration of active forms of $\mathrm{Cu}$ in the north-eastern direction was rather high, although the wind streams are not too frequent here. This fact, as in the previous analysis of the contents of $\mathrm{Cu}$, we associate with the presence of a slight deviation of the area, which causes the receipt of surface runoff from more polluted areas from the eastern part of the territory.

The straight-line dependence of the increase in the concentration of lead in the soils as far as the distance from the source of emission in all directions except the eastern one is reliably observed (Fig. 9). The largest mosaic of soil contamination was marked in the south-eastern direction from 0.1 to $1.7 \mathrm{MPC}$.

The highest value of the lead content of soil is 2 MPCs in the eastern direction, however, the dependence of the changes in the $\mathrm{Pb}$ concentration in the soils from the source of the emission is not marked, since the mosaic of the soil cover at the level of 0.25 to $1.25 \mathrm{MPC}$ is marked throughout the distance from 1 up to $2100 \mathrm{~m}$.

The expressed ellipses of soil contamination by lead are marked in the north-eastern and northern directions. It is precisely on these territories that there is a clear tendency to increase the concentration of $\mathrm{Pb}$ in the soil above $1 \mathrm{mg} \cdot \mathrm{kg}^{-1}$ outside the $1-\mathrm{km}$ zone.

This indicates that lead is distributed with fine dust, and is carried over a distance of more than $1 \mathrm{~km}$. This creates a danger for soil contamination of areas located outside the sanitary protection zone in quantities exceeding MPC (Fig. 10).

Gauss's most peaked curve was in the direction of the least-recurring winds - the north-eastern one, indicating the highest stability of the manganese concentration indicators. The most «flutter» was the «Gauss's bell» in the most critical south-eastern direction.

The south-eastern and eastern directions from the source of emission, as well as in the studies of the previous pollutants, were characterized by the highest median levels of manganese contamination of soil -41.73 and 39.70 $\mathrm{mg} \cdot \mathrm{kg}^{-1}$ respectively (Fig. 11). The values of the content of the Mn moving forms in the north-eastern and northern directions were 33.7148 and $34.9535 \mathrm{mg} \cdot \mathrm{kg}^{-1}$, respectively. And although the average values did not exceed MPC, the values of maximum concentrations were higher than 50 

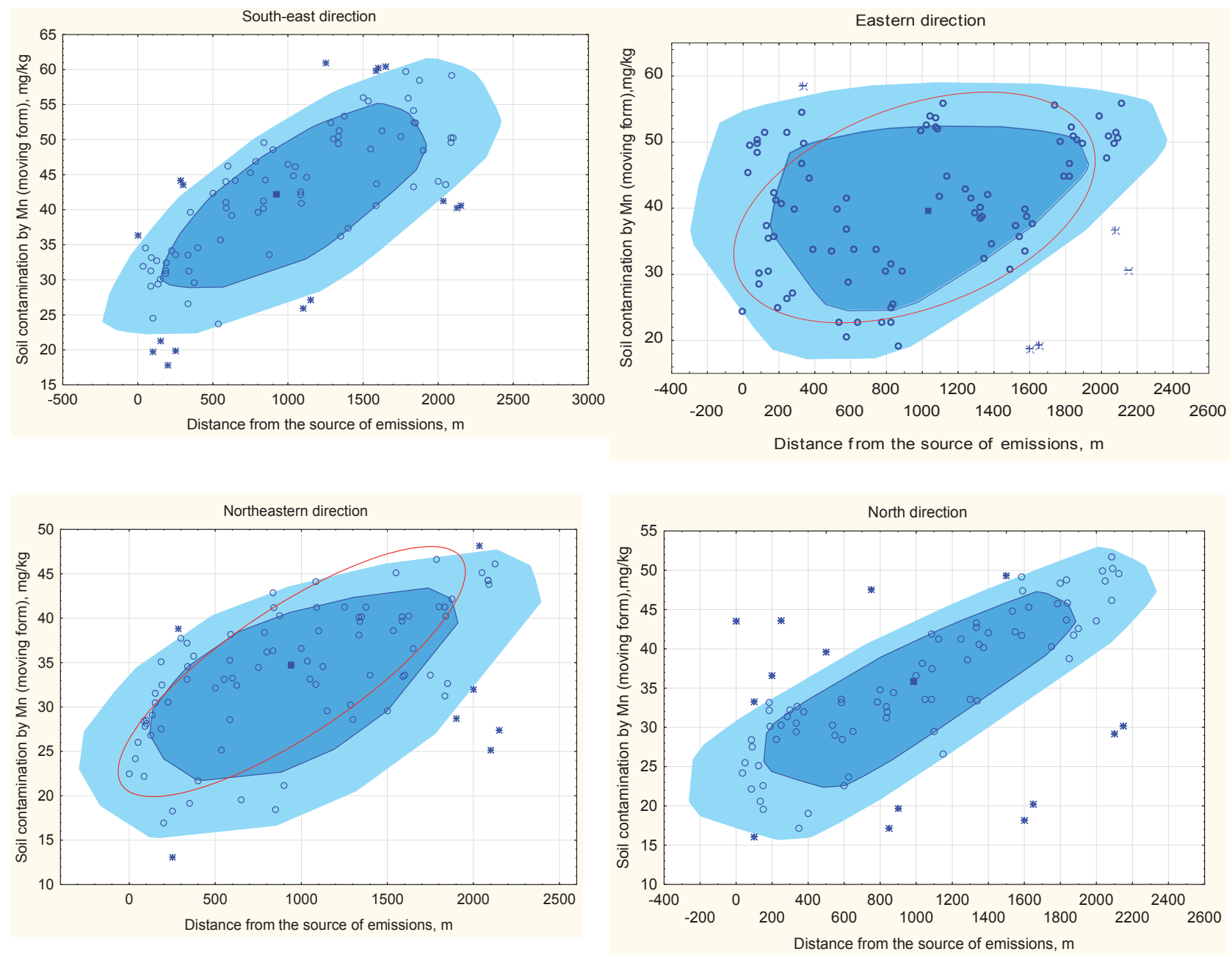

Figure 11. Ellipses of soil contamination by manganese at different distances from the source of emission

$\mathrm{mg} \cdot \mathrm{kg}^{-1}$ in all directions, except for the north-east. Thus, in the south-eastern direction, the variation of the values of $\mathrm{Mn}$ in the soil was marked in the range from 1.2 MPC to $0.36 \mathrm{MPC}$. At about the same level were the values in the eastern direction varying from 1.16 to 0.37 MPC. In the northern direction, the majority of values varied from $1 \mathrm{MPC}$ to $0.32 \mathrm{MPC}$.

In all directions, except the eastern one, there are straightline dependencies on increasing the content of manganese as far from the source of emission for a distance of up to 2 km, characterized by high correlation coefficients: 0.5107 for the south-eastern direction, 0.3027 for the north-eastern and 0.4082 - for the northern direction.

Dispersion of zinc with dust masses provoked soil contamination by zinc. The histogram of the distribution of the values of the concentrations of the zinc active forms in soil in combination with the Gauss's diagram showed the highest medians of zinc concentrations in soil in the south- eastern direction $\left(19.10 \mathrm{mg} \cdot \mathrm{kg}^{-1}\right)$ and the northern direction $\left(18.55 \mathrm{mg} \cdot \mathrm{kg}^{-1}\right)$. Gauss's least peaked diagrams were in the south-eastern and the eastern directions indicating a wide range of variations of values and a significant variability of soil coverage by zinc contamination levels. The least flutter was the Gaussian curve in the north-eastern direction, where the winds are the least frequent (Fig. 12).

The most frequent MPC exceedances $\left(23 \mathrm{mg} \cdot \mathrm{kg}^{-1}\right)$ in the content of active forms of heavy metals are marked in the direction of the north-western wind - about 44\% of the surveyed points are marked by the excessive MPC. The maximum concentration of zinc in soils is marked at $1.48 \mathrm{MPC}$, the minimum is about $0.01 \mathrm{MPC}$. In the eastern direction, at about $40 \%$ of the points there was an excess of MPC. The maximum concentration of zinc in the soils of the eastern direction is marked at $1.34 \mathrm{MPC}$, the minimum is about $0.23 \mathrm{MPC}$. In the northern direction, the range of fluctuations of values was marked at the level 
of $1.25-0.09 \mathrm{MPC}$, while at $39 \%$ of the points there was an excess of MPC. The smallest proportion $-24 \%$ of the points, at which the excess of MPC was recorded, were marked in the north-eastern direction (Fig. 13).

The results of the study of the qualitative and quantitative composition of the pollutants of the soil of the territory of the influence of the eastern industrial facilities show a significant danger to agriculture and health. To evaluate the field of elemental anomalies characterizing the presence of various pollutants in soil, we used the indices of soil saturation by chemical elements and the total index of chemical pollution of soil. The obtained data proved the presence of soil degradation as a result of contamination by the industrial facilities.

In the south-eastern direction, the highest rates of total soil pollution were noted. Two particularly critical zones are marked - a site at a distance of 200-250 m, where the maximum index of soil saturation with the elements is indicated, which speaks of intensive ongoing processes of accumulation of pollutants. In this part, the maximum concentrations for the cooper content, which is mainly dispersed in the form of coarse particles, are noted, and thus it deposits closer to the source of emission. The second critical area in this direction is the site at a distance of 1.5-2 $\mathrm{km}$ from the source of emission, which indicates that the key importance in soil contamination in this direction is occupied by fine particle fractions containing a significant amount of manganese, zinc and lead. Soil saturation indices indicate intensive accumulation processes. This territory is not suitable for obtaining agricultural products, but only for technical crops. Such levels of contamination can cause an increase in the number of diseases and an increase in the number of children who are often sick, children with chronic diseases, with violations of the functional state of the cardiovascular system (Mohmand et al., 2015; Wei et al., 2009; Demková et al., 2017). Keeping a domestic farm on this territory is one of the most common methods of obtaining vegetable products, potatoes, berries, etc. Taking into account the aforementioned all the products received on this territory should be subjected to a strict sanitary control.

In the eastern, north-eastern and northern directions there was a similar trend to higher levels of pollution at a distance of 1500 meters, indicating the receipt the greatest number of pollutants consisting of fine dust. Indices of soil saturation practically everywhere in the eastern direction (3.9494 ... 4.8036), the north-eastern (3.1717 ... 4.6712) and the northern direction $(2.9710 \ldots 4.4208)$ indicate intensive processes of accumulation of heavy metals in the soil under investigation. All the three areas are characterized by soils moderately dangerous categories of pollution levels exceeding the MPC toxic compounds, but not exceeding the rate of trans-locational hazard. The entire area explored in these three parts can be used for growing crops, but

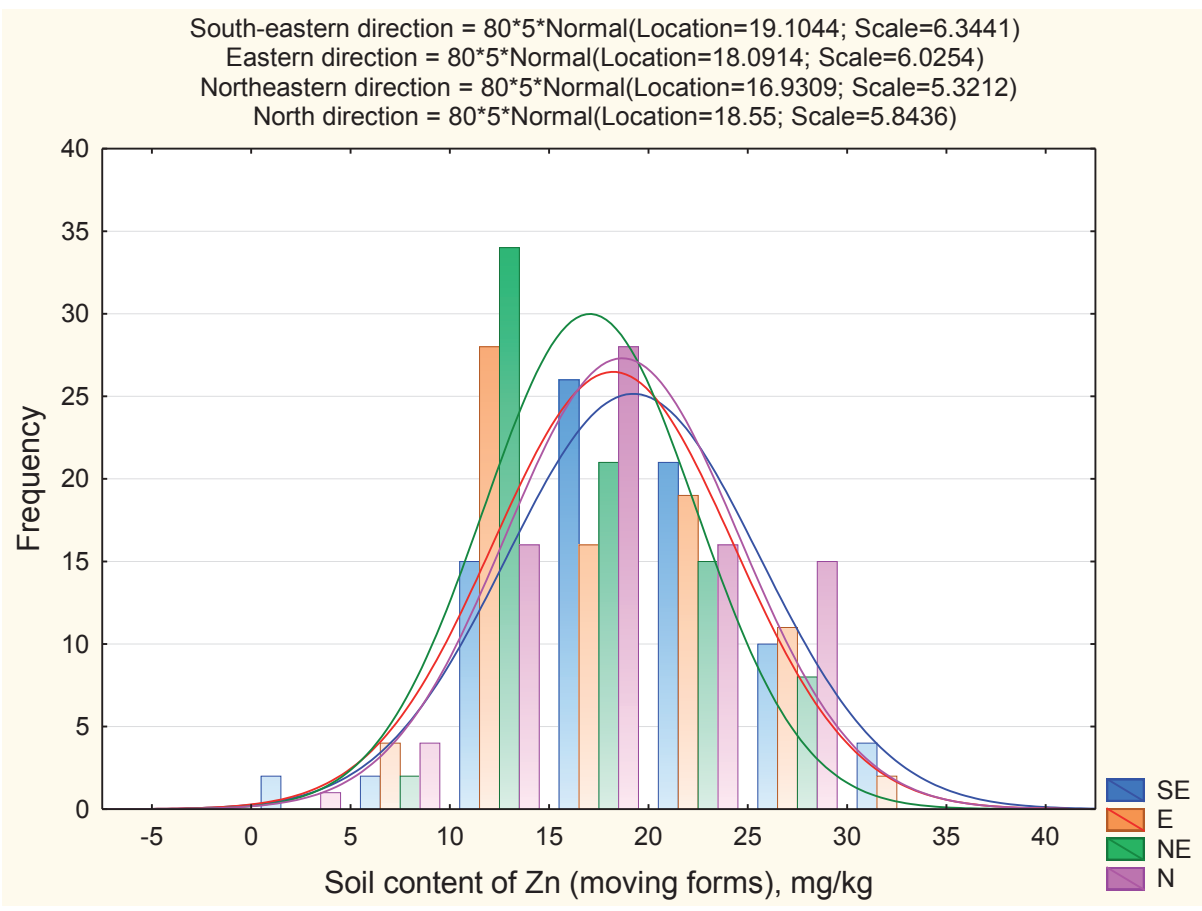

Figure 12. Histogram connected with the Gauss curve, which reflects the variation in the content of the active zinc forms on the areas of prevailing winds 

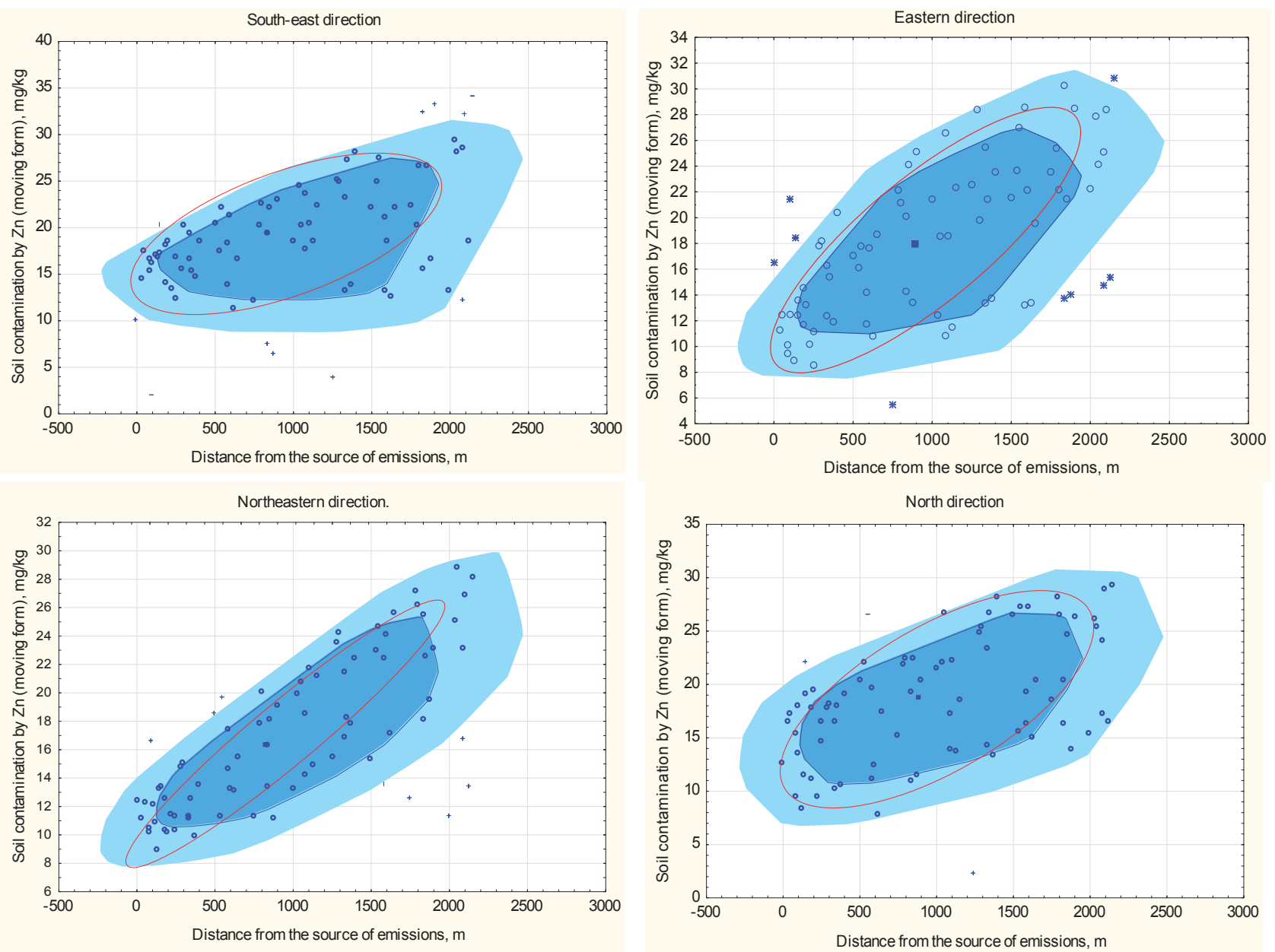

Figure 13. Ellipses of soil contamination by zinc at different distances from the source of emission

the prerequisite is a strict sanitary control of the resulting product.

\section{Conclusions}

Dust pollution of the territory of the eastern industrial facilities of Zhytomyr has a significant negative impact on the surrounding cultivated land. The territory is covered with fertile dark gray podzolized soils and podzolized chernozems, which gives this area a special value. However, the studies have shown that the area is under excessive anthropogenic pressure. Dust samples taken from this territory have made it possible to determine that it has extraordinary toxicity and creates a danger of excessive flow of heavy metals into soils, vegetation, natural waters, etc. The displacement of histograms for the distribution of dust contamination depends on the frequency and direction of the prevailing winds. The highest concentrations of dust in the air were observed in the 400-500-m zone in all studied directions, exceeding the norms of more than 2 MPCs in most cases was noted to a $1-\mathrm{km}$ distance, and above $1 \mathrm{MPC}$ in some places at distances larger than $2 \mathrm{~km}$. The smallest frequency of occurrence of excess of critical points is in the direction of the movement of the south-western wind. The strongest dispersion of dust in the distance from the source of emission is noted for the most intense and repetitive north-western wind. In the dispersion of the dust mass, some regularities are noted, in particular, the greatest danger in the immediate vicinity of the industrial facilities is the formation of copper compounds, which comes in the form of large dust particles, its highest concentrations are noted in a $1-\mathrm{km}$ zone, whereby significant variability of pollution is noted - from 1 to $5 \mathrm{MPC}$, which determines the role of wind streams in creating a general "picture" of pollution. All other investigated groups of pollutants compounds of zinc, lead and manganese, created a danger on more distant territories, due to their receipt in the 
form of a fine particle fraction of dust. The loss of these compounds is also marked by variability and heterogeneity within the studied area, which we also associate with variables of wind characteristics. It is these groups of compounds that pose the greatest hazard for the "well-being" of surrounding industrial sites agroecosystems.

\section{References}

Al-Khashman O.A., 2004, Heavy metal distribution in dust, street dust and soils from the work place in Karak Industrial Estate, Jordan. Atmospheric Environment 38(39): 6803-6812.

Alloway B.J. (ed.)., 2012, Heavy metals in soils: trace metals and metalloids in soils and their bioavailability. Springer Science \& Business Media 22: 11-50.

Babiy A.P., Kharytonov M.M. \& Gritsan N.P., 2003, Connection Between Emissions and Concentrations of Atmospheric Pollutants. In: Melas D., Syrakov D. (eds.) Air Pollution Processes in Regional Scale. NATO Science Series (Series IV: Earth and Environmental Sciences), vol 30. Springer, Dordrecht: 11-19.

Biliaiev M.M. \& Kharytonov M.M., 2011, Numerical Simulation of Indoor Air Pollution and Atmosphere Pollution for Regions Having Complex Topography, [in:] D. Steyn, S. Trini Castelli (eds.) Air Pollution Modeling and its Application XXI. NATO Science for Peace and Security Series C: Environmental Security. Springer, Dordrecht: 87-91.

Ceynowa-Giełdon M., Adamska E. \& Kamiński, D., 2016, An isolated site of calciphilous lichens in the Kujawy region. Ecological Questions 24: 37-43.

Czaja M., Kołton A., Baran A., Muszyńska E. \& Muras P., 2015, Physiological responses of Betula pendula Roth growing in polluted areas. Ecological Questions 22: 39-46.

Dartan G., Taşpınar F. \& Toröz I., 2015, Assessment of heavy metals in agricultural soils and their source apportionment: a Turkish district survey. Environmental Monitoring and Assessment. 187(3): 99.

Demková L., Árvay J., Bobul'ská L., Tomáš J., Stanovič R, Lošák T., Harangozo L., Vollmannová A., Bystrická J., Musilová J. \& Jobbágy J., 2017, Accumulation and environmental risk assessment of heavy metals in soil and plants of four different ecosystems in a former polymetallic ores mining and smelting area (Slovakia). J. Environ. Sci. Health A Tox. Hazard Subst. Environ. Eng. 52(5): 479-490. (doi: $0.1080 / 10934529.2016 .1274169)$.

DSTU 4770.1-9:2007: Yaki`st' g’runtu. Viznachennya vmi`stu rukhomikh spoluk marganczyu (czinku, kadmi `yu, zali`za, kobal'tu, mi`di’, ni`kelyu, khromu, svinczyu) v g`runti` v buferni`j amoni`jno-aczetatni`j vityazhczi` z pH 4.8 metodom atomno-absorbczi jnoyi spektrofotometri yi [Soil quality. Determination of the content of mobile compounds of manganese (zinc, cadmium, iron, cobalt, copper, nickel, chromium, lead) in soil in buffer ammonium acetate extract with $\mathrm{pH} 4.8$ by atomic absorption spectrophotometry] : Chinnij vi`d 01.01. 2009. [Effective 01.01. 2009]. Derzhstandart Ukrayini, Kiyiv 2009. - 9 s. (Naczi onal'nij standart Ukrayini) [National Standard of Ukraine].

Fedoniuk T.P., Fedoniuk R.H., Romanchuk L.D., Petruk A.A. \& Pazych V.M., 2019, The influence of landscape structure on the quality index of surface waters. Journal of Water and Land Development 43: 56-63.

Haiyan W. \& Stuanes A.O., 2003, Heavy metal pollution in air-water-soil-plant system of Zhuzhou City, Hunan Province, China. Water, Air, and Soil Pollution 147(1-4): 79-107.

Harmens H., Mills G., Hayes F. Sharps K., Frontasyeva M. \& the participants of the ICP Vegetation, 2016, Air pollution and vegetation: ICP Vegetation annual report 2015/2016. NERC/Centre for Ecology \& Hydrology, Bangor, UK, 35 pp. (CEH Project no. C05239, C04325).

Hsu M.J., Selvaraj K. \& Agoramoorthy G., 2006, Taiwan's industrial heavy metal pollution threatens terrestrial biota. Environmental Pollution 143(2): 327-334.

Hulisz P., Elvisto T., Karasiewicz M. T. \& Piernik, A., 2011, Abiotic factors influencing the occurrence of $\mathrm{Sa}$ licornia europaea in West Estonia. Ecological Questions 14(1): 57-60.

Imperato M., Adamo P., Naimo D., Arienzo M., Stanzione D. \& Violante P., 2003, Spatial distribution of heavy metals in urban soils of Naples city (Italy). Environmental Pollution 124(2): 247-256.

Zhongmin J., Siyue L. \& Li W., 2018, Assessment of soil heavy metals for eco-environment and human health in a rapidly urbanization area of the upper Yangtze Basin. Scientific Reports 8. (doi: 10.1038/s41598018-21569-6).

Kharytonov M., Benselhoub A., Shupranova L., Kryvakovska R. \& Khlopova V., 2015, Environmental assessment of atmospheric pollution in Dnipropetrovsk province (Ukraine). Studia Universitatis" Vasile Goldis" Arad. Seria Stiintele Vietii (Life Sciences Series) 25(2): 125 .

Kharytonov M., Benselhoub A., Kryvakovska R., Klimkina I., Bouhedja A., Bouabdallah S., Chaabia R. \& Vasylyeva T., 2017, Risk assessment of aerotechnogenic pollution generated by industrial enterprises in Algeria and Ukraine. Studia Universitatis "Vasile Goldiş", Seria Stiintele Vietii 27(2): 99-104.

Kunah O., Pakhomov O., Zymaroieva A., Demchuk N., Skupskyi R., Bezuhla L. \& Vladyka Y., 2018, Agroeconomical and agroecological aspects of the rye ( $\mathrm{Se}$ cale cereale L.) yelds spatial variation within Polesia 
and Foreststeppe zones of Ukraine: the useage of the geographically weighted principal components analysis. Biosystems Diversity 26(4): 276-285.

Mohmand J., Eqani S., Fasola M., Alamdar A., Mustafa I., Ali N., Liu L., Peng S. \& Shen H., 2015, Human exposure to toxic metals via contaminated dust: bioaccumulation trends and their potential risk estimation. Chemosphere 132: 142-151.

Prister B.S. (ed.), 1994, Methodology of general soilagrochemical monitoring of agricultural lands in Ukraine / (Guidance document on solid soilagrochemical monitoring of agricultural lands in Ukraine. K., Effective from 07.07.07).

Romanchuck L.D., Fedonyuk T.P. \& Fedonyuk R.G., 2017a, The model of landscape vegetation influence on the mass transfer processes. Biosystems Diversity 25(3): 203-209.

Romanchuck L.D., Fedonyuk T.P. \& Khant G.O., 2017b, Radiomonitoring of plant products and soils of Polissia during the long-term period after the disaster at the Chornobyl Nuclear Power Plant. Regulatory Mechanisms in Biosystems 8(3): 444-454.

Romanchuk L., Fedonyuk T., Pazych V., Fedonyuk R., Khant G. \& Petruk A., 2018, Assessment of the Stability of Aquatic Ecosystems Development on the Basis of Indicators of the Macrophytes Fluctuating Asymmetry. Eastern-European Journal of Enterprise Technologies 11(94): 54-61.

Shmandiy V.M. \& Gurets L.L., 2015, Algorithm for calculating the technogenic loading from pollutant emissions into the atmosphere. ScienceRise 5. 2 (10): 43-48.

Shuanxi F. \& Xudong W., 2017, Analysis and assessment of heavy metals pollution in soils around $\mathrm{a} \mathrm{Pb}$ and Zn smelter in Baoji City, Northwest China, Human and Ecological Risk Assessment: An International Journal 23(5): 1099-1120.

Shupranova L.V., Khlopova V.M., Kharytonov M.M., 2014, Air Pollution Assessment in the Dnepropetro- vsk Industrial Megapolice of Ukraine, [in:] D. Steyn, P. Builtjes, R. Timmermans (eds.), Air Pollution Modeling and its Application XXII. NATO Science for Peace and Security Series C: Environmental Security. Springer, Dordrecht: 101-104.

Siyue L. \& Zhongmin J., 2018, Heavy metals in soils from a representative rapidly developing megacity (SW China): Levels, source identification and apportionment. Catena 163: 414-423. (https://doi. org/10.1016/j.catena.2017.12.035).

Steinnes E., Allen R.O., Petersen H.M., Rambæk J.P. \& Varskog P., 1997, Evidence of large scale heavy-metal contamination of natural surface soils in Norway from long-range atmospheric transport. Science of the Total Environment 205(2-3): 255-266.

Stravinskienè V., 2011, Pollution of "Akmenès cementas" vicinity: alkalizing microelements in soil, composition of vegetation species and projection coverage. Journal of Environmental Engineering and Landscape Management 19(2): 130-139.

Top management statistics in Zhytomyr region, 2010-2018, URL, www.zt.ukrstat.gov.ua.

Vreča P., Pirc S. \& Šajn R., 2001, Natural and anthropogenic influences on geochemistry of soils in terrains of barren and mineralized carbonate rocks in the $\mathrm{Pb}-\mathrm{Zn}$ mining district of Mežica, Slovenia. Journal of Geochemical Exploration 74(1-3): 99-108.

Wei B., Jiang F., Li X. \& Mu S., 2009, Spatial distribution and contamination assessment of heavy metals in urban road dusts from Urumqi, NW China. Microchem. J. 93: 147-152.

Zymaroieva A., Zhukov O., Fedonyuk T. \& Pinkin A., 2019, Application of geographically weighted principal components analysis based on soybean yield spatial variation for agro-ecological zoning of the territory. Agronomy Research 17(6): 2460-2473. 